\title{
When They're Sixty-Four: \\ Peer Effects and the Timing of Retirement
}

by Kristine M. Brown and Ron A. Laschever

Web Appendix

October 2011 
The following appendices contain additional detail and extensions for the paper "When They're Sixty-Four: Peer Effects and the Timing of Retirement." Appendix I derives the identification result discussed in Section 3.1 of the paper. Appendix II provides additional detail on the data sources and the calculation of some of the key variables. Appendix III discusses additional results and extensions of the results in Sections 4 and 5. Appendix IV provides the details for the simulations discussed in Sections 5 and 6 of the paper. Tables A1 through A8 can be found at the end of this appendix.

\section{Appendix I- Identification using the Reform and Individual Fixed Effects}

We first consider a simple two-person example and show that a differential intervention is necessary. We begin with the case of one period and illustrate the crucial role a differential reform plays. This is an extension of the discussion of Partial Population Intervention in Moffitt (2001), where only one of the two agents is affected by a reform. Note that a differential reform is necessary even when assuming no unobservable group component and that $E\left[\epsilon_{i} \mid x_{i}, Z_{s}, i \in s\right]=0$. To reduce the notational burden, and without loss of generality, we first consider a two-person model, $L$ and $H$, who both belong to school $s$. Further, we assume the existence of a social equilibrium and that $|\rho|<1$. We therefore proceed to assume each agent is affected by the outcomes of her peers rather than the expected value of her peers' outcomes:

$$
\begin{aligned}
& y_{L, s}=\beta_{0}+x_{L}^{\prime} \beta+\gamma Z_{s}+\rho \cdot y_{H, s}+\epsilon_{L, s} \\
& y_{H, s}=\beta_{0}+x_{H}^{\prime} \beta+\gamma Z_{s}+\rho \cdot y_{L, s}+\epsilon_{H, s}
\end{aligned}
$$

Next, define $P_{L}$ and $P_{H}$ the effect of the reform on person $L$ and $H$, and with out loss of generality assume $P_{H}>P_{L}$.

Suppressing the group affiliation $s$, and assuming the contextual effect is summarized by all other covariates (self-excluded) we can write the system of equations:

$$
\begin{aligned}
& y_{L}=\beta_{0}+x_{L}^{\prime} \beta+x_{H}^{\prime} \gamma+\rho \cdot y_{H}+P_{L}+\epsilon_{L} \\
& y_{H}=\beta_{0}+x_{H}^{\prime} \beta+x_{L}^{\prime} \gamma+\rho \cdot y_{L}+P_{H}+\epsilon_{H}
\end{aligned}
$$


Defining $D=P_{H}-P_{L}$, looking at the difference of the above, and rearranging terms we obtain:

$$
y_{H}-y_{L}=\left(x_{H}^{\prime}-x_{L}^{\prime}\right) \frac{(\beta-\gamma)}{1+\rho}+\frac{D}{1+\rho}+\frac{\epsilon_{H}-\epsilon_{L}}{1+\rho}
$$

Recall that $D$ is the difference of the impact of the reform. If $D$ (or a proxy of it) were known, then by estimating the above difference equation, we could identify and estimate $\rho$, the endogenous social effect. ${ }^{1}$ Once $\rho$ is identified one could then identify the contextual effect $\gamma$. Because the exact financial change in the plan can be computed for each individual, we can then compute $D$. Note that absent an endogenous social effect $(\rho=0)$, the difference would just be $D$, the usual estimator. If $D=0$, that is, the reform had the same effect on all participants, then one could not separate out the social effect.

We turn to the more general case, let $P_{i}$ denote the unexpected financial incentive measure faced by agent $i$ in school $s$. There are two time periods: $t=0$ is the pre-reform year, and $t=1$ is the post-reform year, and therefore $P_{i, t=0}=0$ for all $i$. We allow for an individual fixed effect, $\mu_{i}$, (which encompasses the case of a school fixed effect if teachers do not change schools):

$$
\begin{array}{ll}
y_{i, t, s}=\beta_{0}+x_{i, t, s}^{\prime} \beta+\bar{X}_{-i, t, s}^{\prime} \gamma+\rho \bar{Y}_{-i, t, s}+\mu_{i}+\epsilon_{i, t, s} & \text { for } t=0 \\
y_{i, t, s}=\beta_{0}+x_{i, t, s}^{\prime} \beta+\bar{X}_{-i, t, s}^{\prime} \gamma+\rho \bar{Y}_{-i, t, s}+P_{i}+\mu_{i}+\epsilon_{i, t, s} & \text { for } t=1
\end{array}
$$

where we already substituted: $\bar{X}_{-i, t, s}^{\prime}=\frac{1}{n_{s}-1} \sum_{j \in s, j \neq i} x_{j, t}$ and $\bar{Y}_{-i, t, s}^{\prime}=\frac{1}{n_{s}-1} \sum_{j \in s, j \neq i} y_{j, t}$

Denoting $\Delta$ as the time-difference operator $\left(\Delta k=k_{t=1}-k_{t=0}\right)$, and subtracting equation (7.3a) from (7.3b), the first difference with respect to year can be written as:

$$
\Delta y_{i, s}=\Delta x_{i, s}^{\prime} \beta+\Delta \bar{X}_{-i, s}^{\prime} \gamma+\rho \Delta \bar{Y}_{-i, s}+P_{i}+\Delta \epsilon_{i, s}
$$

Assuming that $E\left[\Delta \epsilon_{i, s} \mid P_{i} ; s\right]=0$, taking expectations of both sides of the above equation and rearranging terms yields the reduced-form:

$$
\Delta y_{i, s}=\Delta x_{i, s}^{\prime} \theta_{1}+\Delta \bar{X}_{-i, s}^{\prime} \theta_{2}+\theta_{3} P_{i, s}+\theta_{4} \bar{P}_{-i, s}+\Delta \epsilon_{i, s}
$$

\footnotetext{
${ }^{1}$ This assumes, $E\left[\epsilon_{H}-\epsilon_{L} \mid X, D\right]=0$, and so the reform must be uncorrelated with the unobservable error term. Note that a type of reflection problem exists even if $E\left[\epsilon_{i} \mid x_{i}, Z_{s}, i \in s\right]=0$.
} 
where $\bar{P}_{-i, s}=\frac{1}{n_{s}-1} \sum_{j \in s, j \neq i} P_{j}$. As before, note that if $P_{i}=p_{s}$ for all $i \in s$, one could no longer identify the above equation. Though the expressions for each coefficient $\theta$ depend on the parameters $\beta, \gamma, \rho, \delta$ and the group size $n_{s}$, solving the system of equations, for the above specification, one can derive:

$$
\rho=\frac{\frac{\theta_{4}}{\theta_{3}}\left(n_{s}-1\right)}{\frac{\theta_{4}}{\theta_{3}}\left(n_{s}-2\right)+n_{s}-1}
$$

and hence, the endogenous social effect $\rho$ is identified. As in the two-person case, given that $\rho$ is identified we can then identify the contextual effect $\gamma$. Note that we did not require the existence of a differential reform $(P)$ in both periods.

\section{Appendix II- Additional Institutional Details and Calculations}

\section{II.1 Pension and Institutional Details}

All full-time teachers in LAUSD must participate in a statewide defined benefit retirement plan that is administered through the California State Teachers' Retirement System (CalSTRS). Teachers contribute 8 percent of their salaries to CalSTRS and are vested after five years of CalSTRScovered employment. The early retirement age is 55 and age 60 is considered the normal retirement age. Teachers can elect to receive their retirement benefits as an "unmodified allowance" or choose one of the program's joint and survivor annuity options. Payments under these additional annuity options are an actuarial conversion of the unmodified allowance. The annual value of the "unmodified" lifetime retirement annuity is calculated according to the following formula:

$$
B(R, S)=k(R, S) \times S \times w_{S}^{f}
$$

where $S$ is CalSTRS-covered service, $R$ is retirement age, $w_{S}^{f}$ is final compensation, and $k$ is the benefit factor. Final compensation is the average salary over the last three years of service with one exception. For teachers with twenty-five service years retiring after January 1, 2000, final compensation is salary in the last working year. Note that teacher salaries are determined by collective bargaining and follow a rigid schedule based on years of service and education and development credits. The benefit factor is increasing in service $S$ and in retirement age $R$. The values of the 
benefit factor before and after the first pension reform are in Appendix Table A1. There is an annual 2 percent cost-of-living adjustment of the unmodified allowance. This adjustment is based on the initial benefit value; it does not compound.

The first pension reform went into effect for retirements on or after January 1, 1999. This reform was a product of state legislative bills AB 1102 and AB 1150, which were passed in August 1998. This reform altered the pension benefits solely through changes to the benefit factor, $k$, while the structure of the program and the general allowance formula remained intact. This reform was not funded by an increase in the contribution rate of working teachers. The schedule of the benefit factor as a function of years of service and retirement age for both the pre-reform and post-reform periods is given in Appendix Table A1.

The second pension reform went into effect for retirements on or after January 1, 2001. This reform was a product of state legislative bills AB 1933, which was passed in August 2000. This reform did not change the schedule of the benefit factor $k$. A longevity bonus was added to the annual unmodified annuity of career teachers in the amount of $\$ 2400$ for 30 years of service, $\$ 3600$ for 31 years of service and $\$ 4800$ for 32 years or more of service. This reform was not funded by an increase in the contribution rate of working teachers.

\section{II.2 Pension Wealth and Peak Value Calculations}

Pension wealth for an individual retiring in year $t$ is calculated by the authors based on the observable salaries, service years, and age of each teacher according the formula $P W_{i, s, t}=$ $\sum_{a=t}^{T} \pi_{a \mid t}\left(\frac{1}{1+r}\right)^{a-t} B_{a}\left(k_{t}, S_{t}, w_{S, t}^{f}\right)$, where $\pi_{a \mid t}$ is the probability of living to year $a$ given having lived to year $t$, and was computed from the CDC life-tables by age and $\operatorname{sex}^{2} T$ is the maximum possible age that can be attained and is assumed to be 100, $r$ is the real interest rate and is assumed to be 0.03 . Current-year salary is used as the final compensation, $w_{S, t}^{f}$, in the calculations and is assumed to grow at 0.02 per year for calculations of pension wealth at possible future retirement dates. The service used for $S$ is years of teaching in the LAUSD. This measure will understate a teacher's true service if he or she has worked in another district in California. Pension wealth is calculated as of the last day of the academic year. The cost-of-living adjustment is included and

\footnotetext{
${ }^{2}$ United States Life Tables, 2000. National Vital Statistics Report Volume 51, No. 3.
} 
all financial variables are adjusted to year 2000 dollars.

\section{Appendix III- Additional Results and Mechanisms}

Section III.1 examines the performance of the instrumental variables in further detail. Section III.2 examines whether peers have different effects depending on own characteristics such as race, teaching subject, and gender. We then further examine some possible mechanisms through which the peer effect we find may operate. Section III.3 examines whether the results can be explained by changes in the work environment. Sections III.4 and III.5 focus on two possible types of mechanisms, a retirement-age norm, and how individuals' response to own financial incentives is modified by others' response to the financial features of their pension plans. We find that individuals are not affected by the retirement age of others, but that the financial response of others affects the way individuals interpret their own financial incentives.

\section{III.1 First-Stage and Reduced-Form Results for Shock to Own Financial Measures}

In Table A2 we examine the 2SLS, first-stage, and reduced-form results for the effect of a teacher's own pension financial incentives on his or her retirement decision. Columns 1-3, correspond to the 2SLS results reported in Table 2 (no fixed effects, school fixed effects, teacher fixed effects). In addition, to focus on the effect of own financial characteristics we control for any school level effect (including peer retirements) in column 4 where we include school-by-year fixed effects. Panel A reports the results for the 2SLS specifications in which both own pension wealth and own peak value are instrumented with the unanticipated change to those measures caused by the pension reform. The coefficients are similar across all specifications, including the one with school-byyear fixed effects. The pension wealth shock has the expected positive sign and is statistically significant at conventional levels. The peak value shock has the expected negative sign but it is not statistically different from zero.

Panels B and C of Table A2 show the first stage results for pension wealth and peak value respectively. In all cases, the corresponding pension shock has the larger effect in the first stage

and is statistically significant at the 1 percent level. The F-test of the excluded instruments further demonstrates the strength of the instruments. In Panel D, the instruments are entered directly in an 
OLS regression, replacing the pension wealth and peak value measures. The reduced-form results are qualitatively similar to the 2SLS results. A pension wealth shock of one-hundred thousand dollars in a given year causes a 2.4 to 3.3 percentage point increase in the probability that a teacher retires by the end of that year. The effect of a shock to peak value is weaker and the coefficient is statistically different from zero in one of the four specifications.

\section{III.2 Heterogeneity of the Retirement Peer Effect across Teacher Characteristics}

We explore potential heterogeneity in the retirement peer effect across teachers with different observable characteristics. Within this analysis we also address the concern that the observed peer effect may be driven by the coordinated retirements of married couples working in the same school. For this analysis we combine the primary administrative data set, which does not contain information on race/ethnicity or teaching assignment with a publicly-available annual census of teachers in the Los Angeles Unified School District. These data sets do not have a common individual-level identifier so we perform a simple teacher-level match by school, age, years teaching in LAUSD, and gender. Duplicates on these characteristics in our primary administrative data receive a missing value for race/ethnicity and teaching assignment but are retained in the analysis. Due to duplicates and other factors, the match is incomplete.

Using the augmented data, we build on the specification of column 2 in Table 3 to test whether or not teachers that differ by race/ethnicity, teaching assignment and sex respond differently to the retirements of their peers. These results are presented in columns 1-3, 5, and 7 of Table A5. In each case we include in the regression both the total number of retirements in the same school in the previous year and the interaction of the teacher's own characteristic with the total number of retirements in the same school in the previous year. We use the same instrument for the total number of peer retirements as in Table 3 and the interaction term is instrumented with the interaction of the teacher's own characteristic and the total unanticipated pension wealth shock of the retirementeligible teachers in his or her school in the previous year. We find no evidence of a differential response among whites, African Americans, Hispanics, women, or those assigned to teach math and science classes. In all cases the coefficient on the interaction term is an order of magnitude smaller than the main effect and is not statistically significant. Female teachers are more likely to 
retire all else equal.

In columns 4, 6, and 8 of Table A5, we examine the response of individual retirement behavior to the retirements of those that are similar along an observable dimension. In each specification, the variable of interest is the total number of retirements of teachers of the same race/ethnicity, teaching assignment, or sex in the same school in the previous year. These variables are instrumented with the total unanticipated pension wealth shock for the corresponding group in the previous year. The total number of retirements in the same school in the previous year is also included and instrumented as before. Teachers do not respond differently to the retirements of those that have the same race/ethnicity or teaching assignment (such as math and science) as themselves. The coefficient on these terms is again an order of magnitude smaller than the main effect. Teachers' retirement decisions appear slightly more sensitive to the sex of past retirees. As shown in column 8 , the coefficient on the retirements of teachers of the same sex is larger and negative. However, it is not statistically significant and it is half the magnitude of the coefficient on all retirements, thus providing further evidence that coordinated retirement decisions among couples are not driving most of the observed retirement peer effect.

\section{III.3 Changes to the Work Environment}

Retirements necessarily create churning of teaching faculty. The replacement of (or failure to replace) older, more experienced teachers may affect the working conditions of the remaining teachers. We examine whether it is a change in work environment rather than the retirement of others per se that is affecting individual retirement decisions. We add additional measures of the changes in the characteristics of the faculty at each school to our main specifications. The first four columns of Table A6 build on the specification in column 2 of Table 3, and add, separately, the change in the fraction of teachers with less than two years of teaching experience, the change in the fraction of teachers that are fully credentialed, the percent change in the full-time-equivalent faculty size, and the percent change in the pupil-to-teacher ratio. In all cases, the coefficient on our main peer retirement measure, the number of retirements in the previous year, remains virtually unchanged. The coefficients on the change characteristics are generally small and are not statistically different from zero. Columns 5-8 add school fixed effects. The results remain very similar. 


\section{III.4 Retirement-Age Norms}

One possible way in which individual retirements may be affected by group retirement behavior is if individuals have a preference to retire at the same age as others in their peer group. The occurrence of spikes in the retirement hazard rate at particular ages is well documented (e.g., ages 62 and 65 for Social Security claimants). While these spikes often coincide with the features of the retirement program under study, the program features do not completely explain the bunching of retirees at particular ages. ${ }^{3}$

If a retirement-age norm exists, an individual can increase his or her utility by retiring at this age, all else equal. We incorporate this into our framework by allowing individual utility to also depend on the age distance between the individual's current age and the norm retirement age. The true norm retirement age, if any, is unobserved, so the modal retirement age at a school in the preceding year (or over the two preceding years) is used as the norm retirement age in the estimation. The "age gap" squared, which is equal to the number of years between own age and the modal retirement age squared, is used to capture the effect of the age norm on retirement. Note that our examination of norms focuses on school-specific age-norms. There may be a system-wide (or economy-wide) age norm. Any such norm would be picked up by our age dummy controls.

To test for the importance of school-specific age norms we regress the retirement decision on the age gap and include the same covariates as those included in Table 3. To control for the endogeneity of the retirement decision, we add in the number of peers that retired in the previous year (instrumented as before). These results are presented in columns 1-4 of Table A7. In column 1 we control for the 1-year modal retirement age gap. The coefficient on the age gap is statistically significant at the 5 percent level. The sign indicates that individuals are less likely to retire the further they are from the modal age, however the coefficient is very small in magnitude $(-0.00007$ in column 1). The coefficient on the total number of retirements is slightly larger with the inclusion of this additional control. In column 2 we allow the effect of the age norm to vary if the teacher is older than the modal retirement age. There is no evidence of a difference and no change in the

\footnotetext{
${ }^{3}$ Social norms have been widely suggested as a potential contributing cause of retirement age spikes. For example, see Asch et al. (2005) and Mastrobuoni (2009). However, some structural work has shown that the "unexplained" portion of the retirement age spikes, after controlling for financial incentives, heterogeneous time preferences, etc., is likely to be small (e.g., Gustman and Steinmeier, 2005).
} 
other estimates. Columns 3 and 4 show the results for the same analysis using the 2-year modal retirement age gap. With this age norm measure, age norms appear to have little if any effect on retirement decisions and the estimate of the retirement peer effect is the same as in our main results. Taken together, we interpret the results in this section as evidence that a school-specific norm retirement age (as we have defined it here) does not play a large role in individual retirement decisions and is not driving the differences in retirement behavior across schools.

\section{III.5 The Effect of Others' Change in Financial Incentives and Pension Maximization}

To explore another possible mechanism through which networks may operate, we take advantage of the detailed pension plan information and focus on how others' response to their pension financial incentives and the reform affect individuals' response to their own pension financial measures. Further, whereas the specifications in the previous sections examined the effect of others' outcomes, in this section we examine all peers, including both those who decide to retire and those who do not. This is meant to capture the fact that even those who do not retire themselves might provide information or consultation to those considering retirement.

We first examine the direct financial effect of the reform. The reduced-form specification allows us to examine how changing others' financial incentives affects own response, extending the results reported in Table 4. Column 5 of Table A7 focuses on the interaction between own pension financial incentives and the unexpected change in pension wealth experienced by others due to the reform. The main effect, others' total change in pension wealth is positive and statistically significant. The effect of own peak value is negative, as expected, and statistically significant. The interaction term (own peak value X others' unexpected change in pension wealth) is statistically significant at the 5 percent level, and is negative as expected. This result is consistent with others' change in financial incentives magnifying the effect of an individual's own financial incentives, in this case the potential gain to delaying retirement. It provides a possible mechanism through which individuals respond to an unanticipated financial reform. The result demonstrates that others' financial shocks affect how an individual responds to their own financial situation.

Though the reduced-form results would be sufficient for predicting how a change in financial incentives would propagate through one's peers, we exploit the detailed financial information and 
the panel-nature of our data, to determine how the financial consequences of the timing of retirement may be affected by one's peers. Each individual may gain (or lose) additional pension wealth by delaying retirement, and the effect that this financial option value has on the individual retirement decision may be modified by interactions with peers. We maintain the assumption that people act optimally, and maximize their utility. However, since the financial aspect of a retirement plan is not the only factor entering into an individual's decision, it is possible to retire before the optimal-pension-plan retirement date and thus "leave money on the table." We find that while a large potential future gain in pension wealth associated with delaying retirement reduces the likelihood of retirement (as expected), being surrounded by others who eventually retired before fully maximizing the financial value of their pension plans, largely mitigates the effect of one's own financial option value of delayed retirement. In other words, teachers that are surrounded by others who tend to "leave money on the table" when retiring, all else equal, are more likely to do the same when considering their own retirement.

For any point in time, we can compute whether retirement would maximize pension wealth. We use the peak value measure to compute how much money (in pension wealth) an individual would forgo if she retired today versus the date in the future that maximizes pension wealth. Then, for each retirement that occurs we can evaluate to what extent an individual could have further increased her financial gain by delaying retirement. Using the measures of financial-underutilization, we can examine whether a higher degree of under-utilization among peers within a school moderates the importance an individual places on fully maximizing his own pension wealth.

For every individual in our sample, we look at their eventual retirement dates, and examine the amount each could have gained by waiting to retire. To operationalize the notion of "leaving money on the table", we designate individuals as "Retired-Too-Early-Financially" (RTEF) by whether or not their own peak value measure is over $\$ 50,000$ when they eventually retire (i.e., whether the gap between the present value of pension wealth at the retirement date and the present value of pension wealth at the optimal date is more than $\$ 50,000$ ). Individuals are therefore assigned a value of one if they did not fully maximize the financial aspect of the retirement decision by having a peak value of over $\$ 50,000$ when retiring. ${ }^{4}$ For those who retired after our panel data is over, we code

\footnotetext{
${ }^{4}$ We chose $\$ 50,000$ as a cutoff as it is the upper quartile among those with a positive Peak Value at retirement. Our results are robust to examining higher cutoffs and other measures such as 1-year and 2-year accrual.
} 
their RTEF as zero, and hence our results are a lower bound of the true effect. Because current and future decisions of others are affected by own decision, the simultaneity of the decision requires the use the same instrumental variable strategy used in the previous sections.

The results are presented in column 6 of Table A7. The key variables of interest here are the number of one's peers who are RTEF interacted with whether or not an individual would be RTEF if retired today. The interaction term is positive and statistically significant at the 10-percent level. As to be expected, an individual's own peak value has a negative effect on the probability of retirement, but a higher number of peer RTEFs, that is peers who eventually retire before maximizing their benefits, reduces this effect. For example, in column 6, having a peak value of over $\$ 50,000$ (i.e., retirement today would qualify one as RTEF) reduces the likelihood of retirement by 1.2 percentage points. However, the number of peer RTEFs interacted with whether own peak value is over $\$ 50,000$ increases the likelihood of own retirement by 0.5 percentage points.

There are two, not necessarily mutually exclusive, types of possible explanations consistent with our findings. The first is that a failure to fully maximize pension benefits is a proxy for financial sophistication regarding the program. Hence, less savvy peers might lead an individual to retire at a date that does not fully maximize his or her own benefits. The second is that the preferences of others, in this case preferences that downweight the importance of (pension) financial gain versus leisure, might cause an individual to be less apprehensive about forgoing some financial benefit. In either case, the findings point to a peer interaction that operates through the underlying financial incentives to retire.

\section{Appendix IV- Simulation Details}

\section{IV.1 Couples and Joint Retirement Decisions}

To further address the concern that our estimated peer effect is driven by the coordinated retirement of spouses working in the same school, we simulate the effect of joint retirements on our results. Because we cannot directly observe the partnerships between teachers in our sample, we use Census 2000 data to estimate the fraction of teachers in Los Angeles that are married to another teacher working in the same school. We define potential teacher-co-worker spouses as married couples in 
which both teachers reported providing the same level of instruction (i.e. elementary vs. secondary). We estimate an upper-bound of $4 \%$ for the fraction of teachers in Los Angeles that could be working at the same school as their (teacher) spouses. It is likely that an even smaller fraction of these married couples are actually working at the same school in our urban setting where there are many schools in close proximity. Our estimate would exclude any couples that are not married according to the Census.

In our administrative data, we define potential retirement-eligible couples as an opposite-sex pair, in which both individuals are age 55 or older and work at the same school. For example, if there are five retirement-eligible men and seven retirement-eligible women in a school, there is a maximum of five couples in that school. We use the census estimate of teacher-co-worker spouses as a fraction of all teachers to estimate the maximum number of couples in the district. We then randomly select this number of couples from all possible (randomly-paired) retirementeligible opposite-sex couples across all schools. The number of chosen couples in each school is constrained by the maximum potential couples in that school. We then re-run our estimates on those not designated as members of a couple (the retirements of members of couples are still included in the peer measure and are allowed to affect those not part of a couple.) The remaining estimated peer effect therefore excludes any consecutive-year joint retirements.

Our results suggest that within-school couples are not a plausible explanation for most of the peer effect. Examining 1000 assignment iterations (each with a different random assignment of couples), the effect of the number of peer retirements in the previous year on an individual's own likelihood of retirement ranges from 1.4 to 2.4 percentage points (compared to 1.9 percentage points when all teachers are included and no "couples" are omitted) and is statistically significant at the 5 percent level or better in all cases, with an average p-value of 0.012. As we have assigned couples to maximize the possibility they drive the peer effect (we assumed for all couples that both members are retirement-eligible and working within the same school), our results in the couples simulations are likely a large overestimate of the potential share of the peer effect that can be attributed to couples making joint retirement decisions. 


\section{IV.2 Policy Simulation and the Social Security Population}

We simulate two variations of a reform that raises the normal retirement age, a common policy used to lower benefits. We consider raising the normal retirement age for all teachers from age 60 to 62 and from age 60 to 65. All retirement rates are simulated using the academic years 1999 and 2001 sample. We operationalize the increase in retirement age by "shifting" the "prereform" benefit factor schedule, which has a maximum of 2 percent at age 60 . For each scenario, the maximum of the benefit factor occurs at the new normal retirement age (62 or 65), and the benefit factors at earlier retirement ages are adjusted downward accordingly. We then compare the simulated effect of the increase in retirement age on retirement rates at each age in the following year.

In both cases, ignoring the effect of others' responses to their pensions (while allowing for other school-level characteristics to have an effect) would lead to an underestimate of the reduction in retirement rates by 10.5 to 12.5 percent for those younger than age 60 . At older ages the magnitude of the underestimate increases. Of particular interest is the difference for those at or above the "postreform" normal retirement age (62 or 65). These individuals have no change in their own pension financial incentives, so when peer effects are ignored the simulations reflect no change in behavior. However, when the effect of others is included, the simulated decrease in retirement rates at these ages is 2.2 to 6.7 percent. The positive peer effect we find means that retirement patterns would also be affected in subsequent years, and in turn, the composition of the population would change. Hence, our results are conservative and limited to the immediate one-year short-run response.

To provide a sense of the magnitude of the estimated peer effect we extrapolate our results to the entire US population covered by Social Security. We assume that the strength of the peer effect and the workplace composition of those 65-69 years old are the same as in our sample and impose a normal retirement age of 65 with the program rules as described above. When we extrapolate our results to the 2008 US population of social-security-eligible workers ages 65-69, ignoring peer effects yields an under-prediction of 142,000 retirements, about 3 percent of the size of that agegroup. ${ }^{5}$

\footnotetext{
${ }^{5}$ Social Security population estimates are based on the 2010 U.S. Social Security Annual Statistical Supplement, Table 4.B5, available at: http://www.ssa.gov/policy/docs/statcomps/supplement/2010/4b.html\#table4.b5
} 


\section{References}

Angrist, Joshua and Jorn-Steffen Pischke, Mostly Harmless Econometrics: An Empiricist's Companion, Princeton University Press, 2008.

Asch, Beth, Steven J. Haider, and Julie Zissimopoulos, "Financial incentives and retirement: evidence from federal civil service workers," Journal of Public Economics, 2005, 89 (23), 427-440.

Gustman, Alan L. and Thomas L. Steinmeier, "The Social Security Early Entitlement Age in a Structural Model of Retirement and Wealth," Journal of Public Economics, 2005, 89, 441-463.

Mastrobuoni, Giovanni, "Labor Supply Effects of the Recent Social Security Benefit Cuts: Empirical Estimates Using Cohort Discontinuities," Journal of Public Economics, 2009, 93, 1224-1233.

Moffitt, Robert A., "Policy Interventions, Low-Level Equilibria, and Social Interactions," in S. Durlauf and H. P. Young, eds., Social Dynamics, Washington, D.C.: Brookings Institution Press, 2001, pp. 45-82. 
Table A1: Pre- and Post-Reform Benefit Factor by Age and Service

\begin{tabular}{cccc}
\hline \hline & $\begin{array}{c}\text { Pre-reform } \\
\text { (Academic year 1997) }\end{array}$ & \multicolumn{2}{c}{$\begin{array}{c}\text { Post-reform } \\
\text { (Academic years 1998 and later) }\end{array}$} \\
Age & All & $<30$ & $30+$ \\
\hline 55 & 1.40 & 1.40 & 1.60 \\
56 & 1.52 & 1.52 & 1.72 \\
57 & 1.64 & 1.64 & 1.84 \\
58 & 1.76 & 1.76 & 1.96 \\
59 & 1.88 & 1.88 & 2.08 \\
60 & 2.00 & 2.00 & 2.20 \\
61 & 2.00 & 2.13 & 2.33 \\
62 & 2.00 & 2.27 & 2.40 \\
63 & 2.00 & 2.40 & 2.40 \\
64 & 2.00 & 2.40 & 2.40 \\
65 and beyond & 2.00 & 2.40 & 2.40 \\
\hline
\end{tabular}

Notes: This table reflects the change in the benefit factor due to the first CalSTRS reform (effective January 1, 1999). The benefit factor multiplied by years of service determines the fraction of salary that will be replaced by retirement benefits. For example, an individual that retires at age 60 with 30 years of service would receive an annual retirement benefit of $(2.0 * 30=) 60 \%$ of salary before the reform and $(2.2 * 30=) 66 \%$ of salary following the first reform. 
Table A2: Instrumental Variables of Own Financial Variables (2SLS, First-Stage, and Reduced-Form) All LAUSD Teachers Ages 55-75

\section{(1)}

Panel A. 2SLS, Dependent Variable - Retire

Pension wealth $(\$ 100 \mathrm{k})$

Peak value (\$10k)

Peak value is positive

Panel B. First stage, Dependent Variable - Pension wealth (\$100k)

$\begin{array}{lllll}\text { Unexpected change in own } & 1.126^{* * *} & 1.113^{* * *} & 0.888^{* * *} & 1.032^{* * *} \\ \text { pension wealth }(\$ 100 \mathrm{k}) & (0.023) & (0.022) & (0.007) & (0.022) \\ \text { Unexpected change in own } & -0.049^{* * *} & -0.044^{* * *} & 0.006^{* *} & -0.018^{* * *} \\ \text { peak value }(\$ 10 \mathrm{k}) & (0.003) & (0.003) & (0.002) & (0.004) \\ \text { F-statistic of the excluded instruments } & 2527.44 & 2745.63 & 12361.16 & 2375.09 \\ \text { P-value of above test } & 0.000 & 0.000 & 0.000 & 0.000 \\ \text { Partial R-squared } & 0.12 & 0.12 & 0.38 & 0.08\end{array}$

Panel C. First stage, Dependent Variable - Peak value in cols. 1, 2, 4; Peak value is positive in col. 3

\begin{tabular}{lllll} 
Unexpected change in own & $0.887^{* * *}$ & $0.843^{* * *}$ & -0.002 & $0.671^{* * *}$ \\
pension wealth $(\$ 100 \mathrm{k})$ & $(0.086)$ & $(0.084)$ & $(0.007)$ & $(0.091)$ \\
Unexpected change in own & $1.790^{* * *}$ & $1.721^{* * *}$ & $0.003^{* * *}$ & $1.801^{* * *}$ \\
peak value (\$10k) & $(0.027)$ & $(0.027)$ & $(0.001)$ & $(0.030)$ \\
F-statistic of the excluded instruments & 4310.40 & 3915.69 & 10.67 & 3660.73 \\
P-value of above test & 0.000 & 0.000 & 0.001 & 0.000 \\
Partial R-squared & 0.16 & 0.16 & 0.00 & 0.16 \\
$\begin{array}{l}\text { Panel D. Reduced form, Dependent Variable - Retire } \\
\text { Unexpected change in own }\end{array}$ & $0.024^{*}$ & $0.024^{*}$ & $0.033^{* * *}$ & $0.027^{* *}$ \\
pension wealth (\$100k) & $(0.013)$ & $(0.013)$ & $(0.011)$ & $(0.013)$ \\
Unexpected change in own & $-0.003^{*}$ & -0.002 & -0.002 & -0.003 \\
peak value (\$10k) & $(0.002)$ & $(0.002)$ & $(0.002)$ & $(0.002)$ \\
R-squared & 0.11 & 0.11 & 0.19 & 0.11 \\
\hline Fixed-effects level & & School & Teacher & School x Year \\
Academic years & $1999-2001$ & $1999-2001$ & $1999-2001$ & $1999-2001$ \\
Sample size & 21,296 & 21,296 & 21,296 & 21,296 \\
\hline
\end{tabular}

Notes: * significant at $10 \%$; ** significant at $5 \%$; *** significant at $1 \%$. Standard errors, in parentheses, are clustered at the school level. All specifications control for own salary, years of service, service squared, gender, and include age dummies and year fixed effects. Peer group measures (self-excluded) include number of retirement-eligible (age 55+) teachers and the average age and service of those 55+. School-level measures include pupil-to-teacher ratio, fraction of teachers with a masters degree or higher, fraction of teachers that are female, and average rank on students' standardized math test scores. Specifications without teacher or school fixed effects also include the number of full-time-equivalent teachers and school grade-range (elementary, highschool, etc.). Because column 4 includes school-by-year fixed effects, only individual-level measures are included. The sample includes all teachers that are age 55-75 during at least one of the academic years 19992001 and that do not change schools. Given the sample, teacher fixed effects also include school fixed effects. The F-statistic and partial R-squared were adjusted for multiple endogenous variables using Angrist and Pischke (2009). 
Table A3: Two-Stage-Least-Squares Estimates of Peer Effects with Additional Peer Instrument

\begin{tabular}{|c|c|c|c|c|c|c|c|}
\hline \multicolumn{8}{|c|}{ All LAUSD Teachers Ages 55-75; Dependent variable- Retirement (Panels A-C) } \\
\hline Specification in Table 3 in Paper: & $(2)$ & (3) & $(4)$ & (5) & $(6)$ & $(7)$ & $(8)$ \\
\hline Specification & $\begin{array}{l}\text { IV peer } \\
\text { retirement }\end{array}$ & $\begin{array}{l}\text { IV peer } \\
\text { retirement }\end{array}$ & $\begin{array}{l}\text { IV peer } \\
\text { retirement }\end{array}$ & $\begin{array}{l}\text { IV peer } \\
\text { retirement }\end{array}$ & $\begin{array}{l}\text { IV peer } \\
\text { retirement }\end{array}$ & $\begin{array}{l}\text { IV peer } \\
\text { retirement } \\
\text { and own } \\
\text { financials }\end{array}$ & $\begin{array}{l}\text { IV peer } \\
\text { retirement } \\
\text { and own } \\
\text { financials }\end{array}$ \\
\hline \multicolumn{8}{|c|}{ Panel A. 2SLS (Table 3 in Paper), Dependent Variable - Retire } \\
\hline $\begin{array}{l}\text { Number of retirees among peers } \\
55+\text { in previous year }\end{array}$ & $\begin{array}{l}0.015^{* * *} \\
(0.006)\end{array}$ & $\begin{array}{l}0.015^{* *} \\
(0.007)\end{array}$ & $\begin{array}{l}0.026^{* *} \\
(0.010)\end{array}$ & $\begin{array}{l}0.015^{*} \\
(0.008)\end{array}$ & $\begin{array}{l}0.020^{* *} \\
(0.010)\end{array}$ & $\begin{array}{l}0.021^{* *} \\
(0.010)\end{array}$ & $\begin{array}{l}0.017^{* *} \\
(0.008)\end{array}$ \\
\hline R-squared of second stage & 0.11 & 0.11 & 0.11 & 0.21 & 0.11 & 0.11 & 0.10 \\
\hline \multicolumn{8}{|c|}{ Panel B. Reduced form (corresponding to Panel A) } \\
\hline $\begin{array}{l}\text { Lag total unanticipated change in } \\
\text { pension wealth of peers }(\$ 100 \mathrm{k})\end{array}$ & $\begin{array}{l}0.003 * * * \\
(0.001)\end{array}$ & $\begin{array}{l}0.003^{* *} \\
(0.001)\end{array}$ & $\begin{array}{l}0.004 * * * \\
(0.001)\end{array}$ & $\begin{array}{l}0.002 * \\
(0.001)\end{array}$ & $\begin{array}{l}0.002 * * * \\
(0.001)\end{array}$ & $\begin{array}{l}0.002 * * * \\
(0.001)\end{array}$ & $\begin{array}{l}0.003^{* *} \\
(0.001)\end{array}$ \\
\hline R-squared & 0.11 & 0.11 & 0.12 & 0.22 & 0.11 & 0.11 & 0.19 \\
\hline \multicolumn{8}{|c|}{ Panel C. 2SLS with additional peer IV, estimated using GMM } \\
\hline $\begin{array}{l}\text { Number of retirees among peers } \\
55+\text { in previous year }\end{array}$ & $\begin{array}{l}0.015^{* * *} \\
(0.006)\end{array}$ & $\begin{array}{l}0.014^{* *} \\
(0.007)\end{array}$ & $\begin{array}{l}0.023^{* * *} \\
(0.008)\end{array}$ & $\begin{array}{l}0.011^{*} \\
(0.006)\end{array}$ & $\begin{array}{l}0.019 * * \\
(0.010)\end{array}$ & $\begin{array}{l}0.020^{* *} \\
(0.010)\end{array}$ & $\begin{array}{l}0.010 \\
(0.006)\end{array}$ \\
\hline R-squared of second stage & 0.112 & 0.113 & 0.111 & 0.213 & 0.110 & 0.107 & 0.037 \\
\hline Over-identification J-statistic & 0.009 & 0.305 & 2.692 & 0.612 & 0.081 & 0.058 & 2.16 \\
\hline P-value for the above test & 0.92 & 0.58 & 0.10 & 0.43 & 0.78 & 0.81 & 0.34 \\
\hline
\end{tabular}

\begin{tabular}{lllllllll} 
Panel D. First stage for number of retirees among those & $55+$ in previous year (corresponding to Panel C) \\
Lag total unanticipated change in & $0.196^{* * *}$ & $0.187^{* * *}$ & $0.221^{* * *}$ & $0.226^{* * *}$ & $0.105^{* * *}$ & $0.105^{* * *}$ & $0.208^{* * *}$ \\
$\quad$ pension wealth of peers (\$100k) & $(0.034)$ & $(0.039)$ & $(0.057)$ & $(0.063)$ & $(0.027)$ & $(0.027)$ & $(0.052)$ \\
Lag total unanticipated change in & -0.002 & -0.003 & $-0.008^{* *}$ & $-0.009^{* * *}$ & -0.003 & -0.003 & $-0.007^{* *}$ \\
$\quad$ peak value of peers $(\$ 10 \mathrm{k})$ & $(0.003)$ & $(0.003)$ & $(0.003)$ & $(0.003)$ & $(0.003)$ & $(0.003)$ & $(0.003)$ \\
F-statistic for excluded IV & 16.77 & 11.53 & 8.26 & 7.60 & 7.50 & 7.49 & 5.77 \\
P-value for the above test & 0.000 & 0.000 & 0.000 & 0.000 & 0.000 & 0.000 & 0.000 \\
R-squared of first stage & 0.11 & 0.11 & 0.11 & 0.21 & 0.11 & 0.11 & 0.04 \\
\hline Additional peer service categories & \multicolumn{7}{c}{ Yes } \\
Fixed-effects level & 1999,2001 & 1999,2001 & 1999,2001 & 1999,2001 & $1999-2001$ & $1999-2001$ & $1999-2001$ \\
Academic years & 14,150 & 14,150 & 14,150 & 14,150 & 21,296 & 21,296 & 21,296 \\
Sample size
\end{tabular}

Notes: * significant at 10\%; ** significant at 5\%; *** significant at 1\%. Standard errors, in parentheses, are clustered at the school level. All specifications control for own pension wealth, peak value, salary, years of service, service squared, gender, and include age dummies and year fixed effects. Peer group measures (self-excluded) include number of retirement-eligible (age 55+) teachers and the average age and service of those 55+. School-level measures include pupil-to-teacher ratio, fraction of teachers with a masters degree or higher, fraction of teachers that are female, and average rank on students' standardized math test scores. Specifications without teacher or school fixed effects also include the number of full-time-equivalent teachers and school grade-range (elementary, high-school, etc.). Teacher fixed effects also include school fixed effects. The F-statistic for multiple endogenous variables was adjusted using Angrist and Pischke (2009). In panel B, column 8 , the coefficient of the 2-year lag unexpected change in others' pension wealth (see also Table 4 ) is $0.002 *(0.001)$. In panel D, column 8 , the first-stage coefficient of the 2year lag unexpected change in others' pension wealth on peer retirements is $0.150^{* * *}(0.048)$. The sample includes all teachers that are age 55-75 during at least one of the academic years 1999-2001 and that do not change schools. Panel C computed using iterative GMM. 
Table A4: Estimates of Peer Effects with Additional Two-Year-Lag Peer Instrument

\begin{tabular}{|c|c|c|c|c|c|c|}
\hline \multicolumn{7}{|c|}{ All LAUSD Teachers Ages 55-75; Dependent variable- Retirement (Panels A and C) } \\
\hline Specification in Table 3 in Paper: & (6) & $(7)$ & $(8)$ & $(6)$ & (7) & (8) \\
\hline Specification & $\begin{array}{l}\text { IV peer } \\
\text { retirement }\end{array}$ & $\begin{array}{l}\text { IV peer } \\
\text { retirement } \\
\text { and own } \\
\text { financials }\end{array}$ & $\begin{array}{l}\text { IV peer } \\
\text { retirement } \\
\text { and own } \\
\text { financials }\end{array}$ & $\begin{array}{l}\text { IV peer } \\
\text { retirement }\end{array}$ & $\begin{array}{l}\text { IV peer } \\
\text { retirement } \\
\text { and own } \\
\text { financials }\end{array}$ & $\begin{array}{l}\text { IV peer } \\
\text { retirement } \\
\text { and own } \\
\text { financials }\end{array}$ \\
\hline \multicolumn{7}{|l|}{ Panel A. 2SLS, Dependent Variable - Retire } \\
\hline $\begin{array}{l}\text { Number of retirees among peers } 55+\text { in } \\
\text { previous year }\end{array}$ & $\begin{array}{l}0.009 * * * \\
(0.003)\end{array}$ & $\begin{array}{l}0.010^{* * *} \\
(0.003)\end{array}$ & $\begin{array}{l}0.017^{* *} \\
(0.008)\end{array}$ & $\begin{array}{l}0.009 * * * \\
(0.003)\end{array}$ & $\begin{array}{l}0.010^{* * *} \\
(0.003)\end{array}$ & $\begin{array}{l}0.016^{*} \\
(0.008)\end{array}$ \\
\hline R-squared of second stage & 0.11 & 0.11 & 0.10 & 0.11 & 0.11 & 0.12 \\
\hline \multicolumn{7}{|c|}{ Panel B. First stage for number of retirees among those $55+$ in previous year (corresponding to Panel A) } \\
\hline $\begin{array}{l}\text { 1-year lag total unanticipated change in } \\
\text { pension wealth of peers }(\$ 100 \mathrm{k})\end{array}$ & $\begin{array}{l}0.221^{* * *} \\
(0.028)\end{array}$ & $\begin{array}{l}0.221^{* * *} \\
(0.028)\end{array}$ & $\begin{array}{l}0.151^{* * *} \\
(0.049)\end{array}$ & & & \\
\hline $\begin{array}{l}\text { 2-year lag total unanticipated change in } \\
\text { pension wealth of peers }(\$ 100 \mathrm{k})\end{array}$ & $\begin{array}{l}0.218^{* * *} \\
(0.030)\end{array}$ & $\begin{array}{l}0.218^{* * *} \\
(0.030)\end{array}$ & $\begin{array}{l}0.137 * * * \\
(0.048)\end{array}$ & & & \\
\hline $\begin{array}{l}\text { Total 1- and 2-year lag unanticipated change } \\
\text { in pension wealth of peers }(\$ 100 \mathrm{k})\end{array}$ & & & & $\begin{array}{l}0.220^{* * *} \\
(0.025)\end{array}$ & $\begin{array}{l}0.219 * * * \\
(0.025)\end{array}$ & $\begin{array}{l}0.141^{* * *} \\
(0.047)\end{array}$ \\
\hline F-statistic for excluded IV & 37.94 & 37.75 & 4.80 & 75.69 & 75.27 & 10.34 \\
\hline P-value for the & 0.000 & 0.000 & 0.009 & 0.000 & 0.000 & 0.001 \\
\hline R-squared of first stage & 0.47 & 0.47 & 0.13 & 0.47 & 0.47 & 0.27 \\
\hline \multicolumn{7}{|c|}{ Panel C. Reduced form (corresponding to Panel A) } \\
\hline $\begin{array}{l}\text { 1-year lag total unanticipated change in } \\
\text { pension wealth of peers }(\$ 100 \mathrm{k})\end{array}$ & $\begin{array}{l}0.003^{* * *} \\
(0.001)\end{array}$ & $\begin{array}{l}0.003^{* * *} \\
(0.001)\end{array}$ & $\begin{array}{l}0.003 * * \\
(0.001)\end{array}$ & & & \\
\hline $\begin{array}{l}\text { 2-year lag total unanticipated change in } \\
\text { pension wealth of peers }(\$ 100 \mathrm{k})\end{array}$ & $\begin{array}{l}0.001 \\
(0.001)\end{array}$ & $\begin{array}{l}0.002 * \\
(0.001)\end{array}$ & $\begin{array}{l}0.002 * \\
(0.001)\end{array}$ & & & \\
\hline $\begin{array}{l}\text { Total 1- and 2-year lag unanticipated change } \\
\text { in pension wealth of peers }(\$ 100 \mathrm{k})\end{array}$ & & & & $\begin{array}{l}0.002^{* *} \\
(0.001)\end{array}$ & $\begin{array}{l}0.002^{* * *} \\
(0.001)\end{array}$ & $\begin{array}{l}0.002^{*} \\
(0.001)\end{array}$ \\
\hline R-squared & 0.11 & 0.11 & 0.19 & 0.11 & 0.11 & 0.19 \\
\hline $\begin{array}{l}\text { IV own pension financials } \\
\text { Fixed-effects level }\end{array}$ & & Yes & $\begin{array}{l}\text { Yes } \\
\text { Teacher }\end{array}$ & & Yes & $\begin{array}{l}\text { Yes } \\
\text { Teacher }\end{array}$ \\
\hline Academic years & 1999-2001 & 1999-2001 & $1999-2001$ & 1999-2001 & 1999-2001 & 1999-2001 \\
\hline Sample size & 21,296 & 21,296 & 21,296 & 21,296 & 21,296 & 21,296 \\
\hline \multicolumn{7}{|c|}{$\begin{array}{l}\text { Notes: * significant at } 10 \% \text {; ** significant at } 5 \% \text {; *** significant at } 1 \% \text {. Standard errors, in parentheses, are } \\
\text { clustered at the school level. All specifications control for own pension wealth, peak value, salary, years of service, } \\
\text { service squared, gender, and include age dummies and year fixed effects. Peer group measures (self-excluded) } \\
\text { include number of retirement-eligible (age 55+) teachers and the average age and service of those 55+. School-level } \\
\text { measures include pupil-to-teacher ratio, fraction of teachers with a masters degree or higher, fraction of teachers that } \\
\text { are female, and average rank on students' standardized math test scores. Specifications without teacher or school } \\
\text { fixed effects also include the number of full-time-equivalent teachers and school grade-range (elementary, high- } \\
\text { school, etc.). The sample includes all teachers that are age 55-75 during at least one of the academic years 1999- } \\
2001 \text { and that do not change schools. Teacher fixed effects also include school fixed effects. The F-statistic for } \\
\text { multiple endogenous variables was adjusted using Angrist and Pischke (2009). }\end{array}$} \\
\hline
\end{tabular}


Table A5: Heterogeneity of the Peer Effect by Individual and Peer Characteristics

\begin{tabular}{|c|c|c|c|c|c|c|c|c|}
\hline \multicolumn{9}{|c|}{ s 55-75; 2SLS; Dependent } \\
\hline & (1) & $(2)$ & (3) & (4) & (5) & (6) & (7) & (8) \\
\hline Specification & 2SLS & 2SLS & 2SLS & 2SLS & 2SLS & 2SLS & 2SLS & 2SLS \\
\hline $\begin{array}{l}\text { Number of retirees among } \\
\text { those } 55+\text { in previous year } \\
\text { (self excluded) }\end{array}$ & $\begin{array}{l}0.018^{* * *} \\
(0.007)\end{array}$ & $\begin{array}{l}0.020^{* * *} \\
(0.007)\end{array}$ & $\begin{array}{l}0.019 * * * \\
(0.007)\end{array}$ & $\begin{array}{l}0.020 * * * \\
(0.006)\end{array}$ & $\begin{array}{l}0.020 * * * \\
(0.007)\end{array}$ & $\begin{array}{l}0.024 * * \\
(0.010)\end{array}$ & $\begin{array}{l}0.018^{* *} \\
(0.007)\end{array}$ & $\begin{array}{l}0.022 * * * \\
(0.008)\end{array}$ \\
\hline Characteristic interacted & Is white & $\begin{array}{l}\text { Is African } \\
\text { American }\end{array}$ & $\begin{array}{l}\text { Is } \\
\text { Hispanic }\end{array}$ & & $\begin{array}{l}\text { Teaches } \\
\text { math/sci. }\end{array}$ & & Is female & \\
\hline $\begin{array}{l}\text { Number of retirees interacted } \\
\text { with characteristic above }\end{array}$ & $\begin{array}{l}0.001 \\
(0.006)\end{array}$ & $\begin{array}{l}-0.007 \\
(0.008)\end{array}$ & $\begin{array}{l}-0.000 \\
(0.008)\end{array}$ & & $\begin{array}{l}-0.005 \\
(0.008)\end{array}$ & & $\begin{array}{l}-0.004 \\
(0.005)\end{array}$ & \\
\hline $\begin{array}{l}\text { Number of retirees of same } \\
\text { race/ethnicity }\end{array}$ & & & & $\begin{array}{l}-0.006 \\
(0.007)\end{array}$ & & & & \\
\hline $\begin{array}{l}\text { Number of retirees teaching in } \\
\text { same subject area }\end{array}$ & & & & & & $\begin{array}{l}-0.009 \\
(0.010)\end{array}$ & & \\
\hline Number of retirees of same sex & & & & & & & & $\begin{array}{l}-0.011 \\
(0.009)\end{array}$ \\
\hline Acadel & 1999,2001 & 1999,2001 & 1999,2001 & 1999,2001 & 1999,2001 & 1999,2001 & 1999,2001 & 1999,2001 \\
\hline $\begin{array}{l}\text { R-squared of second stage } \\
\text { Sample size }\end{array}$ & $\begin{array}{l}0.11 \\
10,796 \\
\end{array}$ & $\begin{array}{l}0.11 \\
10,796 \\
\end{array}$ & $\begin{array}{l}0.11 \\
10,796 \\
\end{array}$ & $\begin{array}{l}0.11 \\
9,621 \\
\end{array}$ & $\begin{array}{l}0.11 \\
10,796 \\
\end{array}$ & $\begin{array}{l}0.11 \\
10,760 \\
\end{array}$ & $\begin{array}{l}0.11 \\
14,150 \\
\end{array}$ & $\begin{array}{l}0.11 \\
14,150 \\
\end{array}$ \\
\hline \multicolumn{9}{|c|}{ Panel B- First Stage of the above specifications for the peer effect IV } \\
\hline $\begin{array}{l}\text { Lag total unanticipated change } \\
\text { in pension wealth of peers, self } \\
\text { excluded }(\$ 100 \mathrm{k})\end{array}$ & $\begin{array}{l}0.203^{* * *} \\
(0.034)\end{array}$ & $\begin{array}{l}0.203^{* * *} \\
(0.034)\end{array}$ & $\begin{array}{l}0.205^{* * *} \\
(0.034)\end{array}$ & $\begin{array}{l}0.229 * * * \\
(0.039)\end{array}$ & $\begin{array}{l}0.205^{* * *} \\
(0.034)\end{array}$ & $\begin{array}{l}0.216^{* * *} \\
(0.041)\end{array}$ & $\begin{array}{l}0.176^{* * *} \\
(0.038)\end{array}$ & $\begin{array}{l}0.178^{* * *} \\
(0.037)\end{array}$ \\
\hline cluded IV & 36.16 & 34.84 & 36.06 & 34.36 & 36.09 & 21.71 & 21.62 & 21.66 \\
\hline P-value for the & 0.000 & .000 & 0.000 & 0.000 & 0.000 & 0.000 & 0.000 & 0.000 \\
\hline R-squared of first stage & 0.45 & 0.45 & 0.45 & 0.46 & 0.45 & 0.45 & 0.4 & 0.45 \\
\hline \multicolumn{9}{|c|}{ Panel C- First Stage of the above specifications for the own characteristic X peer effect IV } \\
\hline $\begin{array}{l}\text { Own characteristic } X \\
\text { unanticipated change in } \\
\text { pension wealth of peers }\end{array}$ & $\begin{array}{l}0.203^{* * *} \\
(0.018)\end{array}$ & $\begin{array}{l}0.202 * * * \\
(0.019)\end{array}$ & $\begin{array}{l}0.187 * * * \\
(0.026)\end{array}$ & $\begin{array}{l}0.190 * * * \\
(0.022)\end{array}$ & $\begin{array}{l}0.167 * * * \\
(0.024)\end{array}$ & $\begin{array}{l}0.169 * * * \\
(0.026)\end{array}$ & $\begin{array}{l}0.196 * * * \\
(0.017)\end{array}$ & $\begin{array}{l}0.173^{* * *} \\
(0.020)\end{array}$ \\
\hline F-statistic for excluded IV & 127.06 & 119.23 & 52.02 & 82.25 & 46.69 & 46.99 & 134.47 & 66.09 \\
\hline P-value for the above test & 0.000 & 0.000 & 0.000 & 0.000 & 0.000 & 0.000 & 0.000 & 0.000 \\
\hline R-squared of first stage & 0.56 & 0.57 & 0.61 & 0.35 & 0.67 & 0.31 & 0.51 & 0.30 \\
\hline \multicolumn{9}{|c|}{$\begin{array}{l}\text { Notes: * significant at } 10 \% \text {; ** significant at } 5 \% \text {; *** significant at } 1 \% \text {. Standard errors, in parentheses, are clustered at the } \\
\text { school level. All specifications control for own pension wealth, peak value, salary, years of service, service squared, gender, } \\
\text { and include age dummies and year fixed effects. Peer group measures (self-excluded) include number of retirement-eligible } \\
\text { (age } 55+\text { ) teachers and the average age and service of those } 55+\text {. School-level measures include pupil-to-teacher ratio, } \\
\text { fraction of teachers with a masters degree or higher, fraction of teachers that are female, average rank on students' } \\
\text { standardized math test scores, number of full-time-equivalent teachers and school grade-range (elementary, high-school, } \\
\text { etc.). Columns } 1-3 \text {, and } 5 \text { also include the dummy variable for the characteristic interacted with number of retirees. Column } \\
4 \text { includes dummy variables for white, African American and Hispanic, and column } 6 \text { includes a dummy variable for teaches } \\
\text { math or science. The sample includes all teachers that are age } 55-75 \text { during at least one of the academic years } 1999-2001 \text { and } \\
\text { that do not change schools. The smaller sample sizes in columns } 1-6 \text { are due to the incomplete match between our } \\
\text { administrative data and the additional dataset that includes information on race/ethnicity and teaching assignment. }\end{array}$} \\
\hline
\end{tabular}


Table A6: Retirement-induced Changes in Work Environment

\begin{tabular}{|c|c|c|c|c|c|c|c|c|}
\hline \multicolumn{9}{|c|}{ All LAUSD Teachers Ages 55-75; 2SLS ; Dependent variable- Retirement } \\
\hline & $(1)$ & $(2)$ & (3) & $(4)$ & (5) & (6) & (7) & (8) \\
\hline Specification & 2SLS & 2SLS & 2SLS & 2SLS & 2SLS & 2SLS & 2SLS & 2SLS \\
\hline $\begin{array}{l}\text { Number of retirees among } \\
\text { those } 55+\text { in previous year } \\
\text { (self excluded) }\end{array}$ & $\begin{array}{l}0.016^{* *} \\
(0.007)\end{array}$ & $\begin{array}{l}0.016^{* *} \\
(0.007)\end{array}$ & $\begin{array}{l}0.016^{* *} \\
(0.007)\end{array}$ & $\begin{array}{l}0.016^{* *} \\
(0.007)\end{array}$ & $\begin{array}{l}0.026^{*} \\
(0.014)\end{array}$ & $\begin{array}{l}0.028^{* *} \\
(0.014)\end{array}$ & $\begin{array}{l}0.029 * * \\
(0.013)\end{array}$ & $\begin{array}{l}0.028^{* *} \\
(0.013)\end{array}$ \\
\hline $\begin{array}{l}\text { Change in fraction of teachers } \\
\text { with }<2 \text { yrs experience }\end{array}$ & $\begin{array}{l}-0.000 \\
(0.000)\end{array}$ & & & & $\begin{array}{l}0.000 \\
(0.001)\end{array}$ & & & \\
\hline $\begin{array}{l}\text { Change in fraction of teachers } \\
\text { with full credentials }\end{array}$ & & $\begin{array}{l}0.000 \\
(0.001)\end{array}$ & & & & $\begin{array}{l}-0.000 \\
(0.001)\end{array}$ & & \\
\hline $\begin{array}{l}\text { Percent change in total full- } \\
\text { time equivalent teachers }\end{array}$ & & & $\begin{array}{l}-0.030 \\
(0.031)\end{array}$ & & & & $\begin{array}{l}-0.010 \\
(0.068)\end{array}$ & \\
\hline $\begin{array}{l}\text { Percent change in the pupil-to- } \\
\text { teacher ratio }\end{array}$ & & & & $\begin{array}{l}-0.009 \\
(0.034)\end{array}$ & & & & $\begin{array}{l}-0.019 \\
(0.067)\end{array}$ \\
\hline Fixed-effects level & & & & & School & School & School & School \\
\hline Academic years & 1999,2001 & 1999,2001 & 1999,2001 & 1999,2001 & 1999,2001 & 1999,2001 & 1999,2001 & 1999,2001 \\
\hline $\begin{array}{l}\text { R-squared of second stage } \\
\text { Sample size }\end{array}$ & $\begin{array}{l}0.11 \\
13,973 \\
\end{array}$ & $\begin{array}{l}0.11 \\
13,973 \\
\end{array}$ & $\begin{array}{l}0.11 \\
13,973 \\
\end{array}$ & $\begin{array}{l}0.11 \\
13,973 \\
\end{array}$ & $\begin{array}{l}0.11 \\
13,966 \\
\end{array}$ & $\begin{array}{l}0.11 \\
13,966 \\
\end{array}$ & $\begin{array}{l}0.11 \\
13,966 \\
\end{array}$ & $\begin{array}{l}0.11 \\
13,966 \\
\end{array}$ \\
\hline \multicolumn{9}{|c|}{ Panel B- First Stage of the above specifications for the peer effect IV } \\
\hline $\begin{array}{l}\text { Lag total unanticipated } \\
\text { change in pension wealth of } \\
\text { peers, self excluded }(\$ 100 \mathrm{k})\end{array}$ & $\begin{array}{l}0.179 * * * \\
(0.038)\end{array}$ & $\begin{array}{l}0.180 * * * \\
(0.038)\end{array}$ & $\begin{array}{l}0.185^{* * *} \\
(0.039)\end{array}$ & $\begin{array}{l}0.186 * * * \\
(0.039)\end{array}$ & $\begin{array}{l}0.142^{* *} \\
(0.067)\end{array}$ & $\begin{array}{l}0.143^{* *} \\
(0.066)\end{array}$ & $\begin{array}{l}0.157^{* *} \\
(0.068)\end{array}$ & $\begin{array}{l}0.153^{* *} \\
(0.068)\end{array}$ \\
\hline F-statistic for e & 22.37 & 22.96 & 23.11 & 22.55 & 4.47 & 4.77 & 5.35 & 5.08 \\
\hline P-value for the above test & 0.000 & 0.000 & 0.000 & 0.000 & 0.035 & 0.029 & 0.021 & 0.025 \\
\hline R-squared of first stage & 0.45 & 0.45 & 0.44 & 0.44 & 0.11 & 0.11 & 0.11 & 0.11 \\
\hline \multicolumn{9}{|c|}{$\begin{array}{l}\text { Notes: }{ }^{*} \text { significant at } 10 \% ;{ }^{* *} \text { significant at } 5 \% \text {; }{ }^{* *} \text { significant at } 1 \% \text {. Standard errors, in parentheses, are clustered at the } \\
\text { school level. All specifications control for own pension wealth, peak value, salary, years of service, service squared, gender, } \\
\text { and include age dummies and year fixed effects. Peer group measures (self-excluded) include number of retirement-eligible } \\
\text { (age } 55+\text { ) teachers and the average age and service of those } 55+\text {. School-level measures include pupil-to-teacher ratio, } \\
\text { fraction of teachers with a masters degree or higher, fraction of teachers that are female, and average rank on students' } \\
\text { standardized math test scores. Specifications without school fixed effects also include the number of full-time-equivalent } \\
\text { teachers and school grade-range (elementary, high-school, etc.). The sample includes all teachers that are age } 55-75 \text { during at } \\
\text { least one of the academic years } 1999-2001 \text { and that do not change schools. }\end{array}$} \\
\hline
\end{tabular}


Table A7: Retirement-Age Norms and Effect of Others' Financial Response

\begin{tabular}{|c|c|c|c|c|c|c|}
\hline \multicolumn{7}{|c|}{ All LAUSD Teachers Ages 55-75; 2SLS (columns 1-4, 6) OLS (column 5); Dependent variable- Retirement } \\
\hline Specification & 2SLS & 2SLS & 2SLS & 2SLS & Reduced & 2SLS \\
\hline $\begin{array}{l}\text { Number of retirees among those } 55+\text { in } \\
\text { previous year (self excluded) }\end{array}$ & $\begin{array}{l}0.021^{* *} \\
(0.009)\end{array}$ & $\begin{array}{l}0.021^{* *} \\
(0.009)\end{array}$ & $\begin{array}{l}0.016^{* *} \\
(0.007)\end{array}$ & $\begin{array}{l}0.016^{* *} \\
(0.007)\end{array}$ & & \\
\hline $\begin{array}{l}\text { 1-year modal retirement age gap } \\
\text { (squared) }\end{array}$ & $\begin{array}{l}-0.000 * * \\
(0.000)\end{array}$ & $\begin{array}{l}-0.000^{* *} \\
(0.000)\end{array}$ & & & & \\
\hline $\begin{array}{l}\text { Older than 1-year modal retirement age } \\
\mathrm{X} \text { age gap }\end{array}$ & & $\begin{array}{l}-0.000 \\
(0.000)\end{array}$ & & & & \\
\hline $\begin{array}{l}\text { 2-year modal retirement age gap } \\
\text { (squared) }\end{array}$ & & & $\begin{array}{l}-0.000 \\
(0.000)\end{array}$ & $\begin{array}{l}-0.000 \\
(0.000)\end{array}$ & & \\
\hline $\begin{array}{l}\text { Older than 2-year modal retirement age } \\
\mathrm{X} \text { age gap }\end{array}$ & & & & $\begin{array}{l}-0.000 \\
(0.000)\end{array}$ & & \\
\hline $\begin{array}{l}\text { Lag total unanticipated change in } \\
\text { pension wealth of peers }\end{array}$ & & & & & $\begin{array}{l}0.003^{* * *} \\
(0.001)\end{array}$ & \\
\hline Own peak value $(\$ 10 \mathrm{k})$ & $\begin{array}{l}-0.006 * * * \\
(0.001)\end{array}$ & $\begin{array}{l}-0.006 * * * \\
(0.001)\end{array}$ & $\begin{array}{l}-0.006^{* * *} \\
(0.001)\end{array}$ & $\begin{array}{l}-0.006^{* * *} \\
(0.001)\end{array}$ & $\begin{array}{l}-0.005^{* * *} \\
(0.001)\end{array}$ & $\begin{array}{l}-0.004^{* * *} \\
(0.001)\end{array}$ \\
\hline \multicolumn{2}{|c|}{$\begin{array}{l}\text { Lag unanticipated change in pension wealth of } \\
\text { peers X own peak value }\end{array}$} & & & & \multirow[t]{2}{*}{$\begin{array}{l}-0.001^{* *} \\
(0.000)\end{array}$} & \\
\hline $\begin{array}{l}\text { Number of peers with eventual peak } \\
\text { value over \$50k at retirement (RTEFs) }\end{array}$ & & & & & & $\begin{array}{l}-0.011 \\
(0.034)\end{array}$ \\
\hline \multicolumn{2}{|c|}{$\begin{array}{l}\text { Number of peers with eventual peak value over } \\
\$ 50 \mathrm{k} \text { X own peak value over } \$ 50 \mathrm{k}\end{array}$} & & & & & $\begin{array}{l}0.051^{*} \\
(0.027)\end{array}$ \\
\hline \multicolumn{2}{|c|}{ Own peak value over $\$ 50 \mathrm{k}$} & & & & & $\begin{array}{l}-0.124 * * * \\
(0.040)\end{array}$ \\
\hline Control for additional financial variables & Yes & Yes & Yes & Yes & Yes & Yes \\
\hline Academic years & 1999,2001 & 1999,2001 & 1999,2001 & 1999,2001 & $1999-2001$ & $1999-2001$ \\
\hline $\begin{array}{l}\text { R-squared of second stage } \\
\text { Sample size }\end{array}$ & $\begin{array}{l}0.003 \\
9,477 \\
\end{array}$ & $\begin{array}{l}0.003 \\
9,477 \\
\end{array}$ & $\begin{array}{l}0.113 \\
11,530 \\
\end{array}$ & $\begin{array}{l}0.113 \\
11,530 \\
\end{array}$ & $\begin{array}{l}0.115 \\
21,296 \\
\end{array}$ & $\begin{array}{l}0.090 \\
21,296 \\
\end{array}$ \\
\hline \multicolumn{7}{|c|}{ Panel B- First Stage of the above specifications for the peer effect IV } \\
\hline $\begin{array}{l}\text { Lag total unanticipated change in } \\
\text { pension wealth of peers, self } \\
\text { excluded ( } \$ 100 \mathrm{k})\end{array}$ & $\begin{array}{l}0.157 * * * \\
(0.042)\end{array}$ & $\begin{array}{l}0.155^{* * *} \\
(0.042)\end{array}$ & $\begin{array}{l}0.183^{* * * *} \\
(0.024)\end{array}$ & $\begin{array}{l}0.182 * * * \\
(0.039)\end{array}$ & \multirow{3}{*}{$\begin{array}{l}\text { Col. 6: change } \\
\text { in PW of peers } \\
\text { X own } \\
\text { unexpected } \\
\text { change in PK }\end{array}$} & $\begin{array}{l}0.003 * * * \\
(0.001)\end{array}$ \\
\hline $\begin{array}{l}\text { F-statistic for excluded IV } \\
\text { P-value for the above test }\end{array}$ & $\begin{array}{l}14.28 \\
0.0000\end{array}$ & $\begin{array}{l}14.04 \\
0.0000\end{array}$ & $\begin{array}{l}22.38 \\
0.0000\end{array}$ & $\begin{array}{l}22.30 \\
0.0000\end{array}$ & & $\begin{array}{l}12.71 \\
0.0004\end{array}$ \\
\hline R-squared of first stage & 0.096 & 0.097 & 0.392 & 0.392 & & 0.412 \\
\hline
\end{tabular}

Notes: * significant at $10 \%$; ** significant at $5 \%$; *** significant at $1 \%$. Standard errors, in parentheses, are clustered at the school level. All specifications control for own pension wealth, salary, years of service, service squared, gender, and include age dummies and year fixed effects. Peer group measures (self-excluded) include number of retirementeligible (age 55+) teachers and the average age and service of those 55+. School-level measures include pupil-toteacher ratio, fraction of teachers with a masters degree or higher, fraction of teachers that are female, average rank on students' standardized math test scores, number of full-time-equivalent teachers and school grade-range (elementary, high-school, etc.). The sample includes all teachers that are age 55-75 during at least one of the academic years 19992001 and that do not change schools. In columns 1-4, the modal retirement age (and age gap) are missing for schools that had no retirements in the previous year (or two years). 
Table A8: Additional Specifications and Robustness Checks (Reduced Form)

\begin{tabular}{|c|c|c|c|c|c|c|c|c|}
\hline & (1) & (2) & (3) & (4) & (5) & (6) & (7) & (8) \\
\hline Specification & Logit & OLS & OLS & OLS & OLS & OLS & OLS & OLS \\
\hline $\begin{array}{l}\text { Lag unanticipated change in } \\
\text { pension wealth of peers } \\
(\$ 100 \mathrm{k})\end{array}$ & $\begin{array}{l}0.044^{* * *} \\
(0.014) \\
{[0.002]}\end{array}$ & $\begin{array}{l}0.003^{* *} \\
(0.001)\end{array}$ & $\begin{array}{l}0.004^{* * * *} \\
(0.001)\end{array}$ & $\begin{array}{l}0.005^{* * * *} \\
(0.001)\end{array}$ & $\begin{array}{l}0.004 * * * \\
(0.001)\end{array}$ & $\begin{array}{l}0.002^{*} \\
(0.001)\end{array}$ & $\begin{array}{l}0.001 * \\
(0.001)\end{array}$ & $\begin{array}{l}0.001 * \\
(0.001)\end{array}$ \\
\hline $\begin{array}{l}\text { Unexpected change in own } \\
\text { pension wealth }(\$ 100 \mathrm{k})\end{array}$ & & & & & & & $\begin{array}{l}0.031 * * * \\
(0.011)\end{array}$ & $\begin{array}{l}0.031^{* * *} \\
(0.011)\end{array}$ \\
\hline $\begin{array}{l}\text { Unexpected change in own } \\
\text { peak value }(\$ 10 \mathrm{k})\end{array}$ & & & & & & & $\begin{array}{l}-0.002 \\
(0.001)\end{array}$ & $\begin{array}{l}-0.002 \\
(0.001)\end{array}$ \\
\hline $\begin{array}{l}\text { All school and peer measures } \\
\text { are lagged }\end{array}$ & & Yes & & & & & & \\
\hline $\begin{array}{l}\text { Peer measures include those } 45 \\
\text { and older }\end{array}$ & & & Yes & & & & & \\
\hline $\begin{array}{l}\text { Condition on those over } 55 \\
\text { during first reform (1999) }\end{array}$ & & & & Yes & & & & \\
\hline $\begin{array}{l}\text { Control for every possible } \\
\text { location on salary schedule }\end{array}$ & & & & & Yes & Yes & & \\
\hline $\begin{array}{l}\text { Include those who moved } \\
\text { between schools }\end{array}$ & & & & & & & Yes & Yes \\
\hline Fixed-effects level & & & School & School & School & $\begin{array}{l}\text { Teacher } \\
\text { (includes } \\
\text { school) }\end{array}$ & Teacher & $\begin{array}{l}\text { Teacher } \\
\text { and } \\
\text { school }\end{array}$ \\
\hline Clustered standard errors level & School & School & School & School & School & School & $\begin{array}{l}\text { School \& } \\
\text { teacher }\end{array}$ & $\begin{array}{l}\text { School \& } \\
\text { teacher }\end{array}$ \\
\hline Academic years & 1999,2001 & 1999,2001 & 1999,2001 & 1999,2001 & 1999,2001 & 1999,2001 & 1999-2001 & $1999-2001$ \\
\hline R-squared (pseudo in col. 1) & 0.18 & 0.11 & 0.12 & 0.11 & 0.12 & 0.22 & 0.19 & 0.20 \\
\hline Sample size & 14,150 & 14,142 & 14,150 & 12,419 & 14,150 & 14,150 & 22,144 & 22,144 \\
\hline
\end{tabular}

Notes: * significant at $10 \%$; ** significant at $5 \%$; *** significant at $1 \%$. Standard errors, in parentheses, are clustered at the school level. In columns 7 and 8 standard errors are clustered two-way at school and individual level. Marginal effect, evaluated at the mean, in squared brackets. All specifications control for own pension wealth, peak value, salary, years of service, service squared, gender, and include age dummies and year fixed effects. Peer group measures (self-excluded) include number of retirement-eligible (age 55+) teachers and the average age and service of those 55+. Peer group measures are those $45+$ in column 3 . School-level measures include pupil-to-teacher ratio, fraction of teachers with a masters degree or higher, fraction of teachers that are female, and average rank on students' standardized math test scores. Specifications without teacher or school fixed effects also include the number of full-time-equivalent teachers and school grade-range (elementary, high-school, etc.). The sample in columns 1-3, and 5-6 includes all teachers that are age 55-75 during at least one of the academic years 1999-2001 and that do not change schools. 